\title{
Os Projetos De Cooperação Entre Brasil E África No Combate À Aids (2008-
}

\section{2)}

Bruno Santos de Araujo Fernandes ${ }^{1}$

\section{RESUMO}

Este trabalho tem por objetivo analisar os projetos de cooperação entre o Brasil e o continente africano relacionados ao combate a AIDS/HIV entre o segundo governo Lula da Silva e os dois primeiros anos do governo Dilma Rousseff relacionando estes projetos a uma breve analise analise dos principais aspectos das diplomacias e políticas africanas dos referidos governos.

Palavras-chave: AIDS; África; Política Externa Brasileira.

A diplomacia do governo Lula destaca-se por características peculiares. De acordo com o embaixador Paulo Roberto Almeida a grande prioridade na conquista por um assento no Conselho de Segurança da Organização das Nações Unidas, a ênfase na cooperação Sul-Sul, a participação em alianças estratégicas (IBAS e BRICs) e um destaque para a África na diplomacia brasileira, foram as marcas do governo (ALMEIDA, 2004, p.162).

O professor José Flávio Sombra Saraiva (SARAIVA, 2012, p. 99) afirma que Lula e a diplomacia brasileira inovaram ao substituir o discurso culturalista pelo discurso de dívida histórica com a África . O professor Pio Penna Filho (PENNA FILHO, 2009, p. 19091) destaca: os países membros da CPLP (Comunidade dos Países de Língua Portuguesa) foram os maiores beneficiados com a cooperação brasileira com o continente africano, porém não foram os únicos, e ressalta Gana como o país anglófono que recebeu importantes projetos brasileiros. Paulo Visentini (VISENTINI, 2013, p. 127) afirma que, apesar das diferenças de temperamento da presidenta Dilma - com perfil mais técnico, cetralizador e mais introspectivo que o do presidente Lula -, os principais aspectos da diplomacia anterior foram mantidos, inclusive as relações com a África.

Em Botsuana, um projeto assinado em 2009, propõe a capacitação cerca de 80 profissionais multiplicadores, que trabalhem diretamente com o tema, por meio de

${ }^{1}$ Mestrando no Programa de Pós-Graduação em Ciência Política da UFPR. 
seminários e workshops. Com isso, a Agência Brasileira de Cooperação (ABC) investiu U\$ 265.410,00 (BRASIL, 2013, p.37). Outro dado importante: com 16\% do orçamento gasto, já foram realizados $80 \%$ das ações. Gana recebeu o projeto chamado fortalecendo as ações de combate a HIV/AIDS em Gana assinado em 2008 e com investimento da ABC de U\$ 50.990,00 e capacitação de 25 profissionais. 50\% das atividades foram resolvidas (BRASIL, 2013, p.85).

No Quênia, a ABC investiu pouco mais de 260 mil dólares (BRASIL, 2013, p.134) em um projeto que objetiva reduzir o impacto da epidemia de DST/HIV/AIDS, por meio da formulação de políticas públicas para o tema e do fortalecimento da assistência e tratamento de soropositivos e gerenciamento de cadeia de suprimento de logística e pesquisa de resistência a medicamento de HIV. ONGs quenianas já haviam realizado intercâmbio da experiência brasileira em mobilização de organizações nãogovernamentais e de pessoas vivendo com HIV/ADS em ações e políticas governamentais.

Em 2009 foi assinado o termo de ajuste do projeto Fortalecimento do Combate ao HIV/AIDS na Tanzânia. Através do fortalecimento das estratégicas de combate e prevenção em favor de populações vulneráveis, do combate através de estratégias de prevenção da AIDS no local de trabalho, e do fortalecimento dos programas de saúde sexual e reprodutiva no setor da educação. Para tal, realizar-se-ão cursos e oficinas, com vistas a capacitar os técnicos tanzanianos. A ABC investiu 204 mil dólares. Até então, foram realizadas $48 \%$ das atividades.

Em Burquina Faso houve um projeto de apoio ao fortalecimento da resposta nacional ao HIV/AIDS e hepatites virais. As principais demandas e necessidades identificadas foram: descentralizar o atendimento das pessoas que vivem com HIV/AIDS; aumentar a cobertura dos tratamentos; realizar triagem e tratamento de pacientes com hepatites virais; melhorar a logística da distribuição de medicamentos; melhorar o treinamento de médicos pediatras e enfermeiras para o tratamento de crianças com HIV/AIDS. Com isso, o Investimento Brasileiro foi de 170 mil dólares e o acordo assinado em 2009 (BRASIL, 2013, p. 189).

Na República do Congo ocorre o projeto de Fortalecimento do Combate ao HIV/AIDS, com investimento de 219 mil dólares pela ABC (BRASIL, 2013, p.147). As 
principais ações são: conhecimentos em políticas públicas nacionais de HIV/AIDS do Brasil; desenvolvimento de estratégias de prevenção para populações vulneráveis, com enfoque em profissionais do sexo; capacidade de mobilização e atuação da sociedade civil; capacitação em assistência e tratamento a Pessoas Vivendo com HIV, especialmente no tratamento da resistência viral.

Em 2010 foi assinado um acordo de cooperação com Zâmbia para implementar o projeto de fortalecimento do plano estratégico nacional para HIV/AIDS. As principiais atividades realizadas foram: visita técnica sobre aquisição de medicamentos de HIV/AIDS (cinco técnicos zambianos); visita técnica sobre saúde e prevenção nas escolas (SPE), com a participação de 5 técnicos zambianos; Assistência e tratamento às pessoas vivendo com HIV/AIDS (8 técnicos zambianos); e Workshop sobre governo e sociedade Civil (5 técnicos) (Brasil, 2013, p.200). No projeto estabelecido em GuinéBissau, a cooperação foi além da educação e conscientização, incluindo áreas de manejo clínico de antirretrovirais, infecções oportunistas e infecções tuberculosas desenvolvidas. Assinado em 2010, a ABC investiria US\$257,900.00 , caso a cooperação não tivesse sido suspensa devido ao golpe de estado ocorrido naquele ano (BRASIL, 2013, p.95).

Moçambique foi o palco do maior e mais importante projeto de cooperação relacionado ao combate a AIDS, com a construção da fábrica de medicamentos antirretrovirais. Tal iniciativa remonta ao primeiro ano do governo Lula. A sociedade Moçambicana de Medicamentos não produzirá somente remédios para a AIDS e quando a produção estiver a pleno vapor, a fábrica terá capacidade para produzir pelo menos 21 tipos de remédios, que vão dos anti-inflamatórios aos usados no tratamento de tuberculose, malária, hipertensão e diabetes tipo 2 (PENNA FILHO, 2013). 0 Governo brasileiro estima investir 21 milhões de dólares nesse projeto, e é responsável ainda pela transferência de tecnologia em todo o processo de fabricação de medicamentos e pela capacitação para o gerenciamento da nova unidade produtiva. 0 governo moçambicano, por sua vez, ficou encarregado de identificar, adquirir e preparar o local da construção da planta industrial e fazer a seleção do pessoal que irá administrar e trabalhar na nova fábrica.

Somando-se os projetos aqui mencionados o Governo Brasileiro através da ABC e do Ministério da Saúde investiu aproximadamente 1,8 milhão de dólares nesses 
projetos, sem contar os investimentos na Sociedade Moçambicana de Medicamentos. Muitos deles foram assinados no governo Lula, porém, apenas implementados no governo Dilma, demonstrando assim a continuidade plena nos projetos de cooperação. No atual governo, houve um movimento de cooperação rumo à África de expressão francesa, demonstrando aprofundamento do universalismo da política Africana. É fundamental destacar: a África do Sul; o Reino do Lesoto; a República Democrática do Congo; e Malaui demonstraram interesses em receber projetos de cooperação do Brasil no Combate a AIDS, que devem ser atendidos de acordo com o orçamento da ABC.

\section{Referências Bibliográficas}

ALMEIDA, Paulo Roberto de. Uma Política Externa Engajada: a Diplomacia do Governo Lula. Revista. Brasileira de Política Internacional. vol.47 no.1. Brasília: Janeiro/Junho 2004. p. 162-184.

BRASIL, Ministério das Relações Exteriores. Informações sobre projeto da ABC: África. Brasília: 2013.

PENNA FILHO, Pio. A África Contemporânea: do Colonialismo aos dias atuais. Brasília: Hinterlândia Editorial, 2009.

Cooperação com Moçambique: 0 Brasil e a Sociedade Moçambicana de Medicamentos. Disponível em: $<$ http://observatoriodaafrica.wordpress.com/2012/07/19/cooperacao-commocambique-o-brasil-e-a-sociedade-mocambicana-de-medicamentos/>. Acesso em 31 de maio 2013.

SARAIVA, José Flavio Sombra. África Parceira do Brasil Atlântico: Relações Internacionais do Brasil e da África no Início Século XXI. Belo Horizonte: Fino Traço, 2012.

VISENTINI, Paulo Fagundes. A projeção Internacional do Brasil: 1930-2012. Rio de Janeiro: Elsevier, 2013. 